\title{
Pengaruh Komunikasi Efektif terhadap Kepuasan Pernikahan pada Pasangan yang Melakukan Pernikahan Dini
}

\author{
Melalita Jamhur Adhea Dwima \\ Fakultas Psikologi, Universitas Muhammadiyah Malang \\ E-mail: Melalitajamhur16@gmail.com
}

\begin{abstract}
Early marriage is a wedding done by an underage couple whose preparations are not said to be ripe, such as physical preparation, mental preparation and matter. Because it does not have a mature preparation to encourage the occurrence of a biceking or conflict in his marriage and affect his satisfaction. A conflict or problem needs a communication in it. Good commissioning is an effective communication which is an action or activity undertaken to maintain the relationship by conveying something with what it is, not cutting the conversation of the adversary, and going through the advice given by the interlocutor. The purpose of this research is to know the influence of effective communication on marriage satisfaction in couples who do early marriage. The type of research used is simple linear regression with research subjects 100 couples who marry early with a range of ages 16-19 years. The sampling technique used is purposive sampling. The results of research showed that there was an influence between effective communication and marriage satisfaction in couples who performed early marriage with a value of 0.000 .
\end{abstract}

KEYWORDS Early-Age marriage, effective communication, marriage satisfaction.

CITATION Dwima, Melalita. (2019). Pengaruh komunikasi efektif terhadap kepuasan pernikahan pada pasangan yang melakukan pernikahan dini. Cognicia.

Menurut Undang Undang Nomor 1 Tahun 1974 pasal 1 pernikahan merupakan sebuah ikatan lahir antara pria dan wanita sebagai suami istri dengan tujuan membentuk keluarga atau rumah tangga yang bahagia sejahtera serta kekal berdasarkan ketuhanan yang maha esa. Sebagaimana yang ada pada UndangUndang perkawinan No. 1 tahun 1974 pasal 7 yang mengatakan bahwa perkawinan hanya diizinkan jika pihak pria sudah mencapai usia 19 tahun dan pihak wanita sudah mencapai usia 16 tahun, namun batas usia tersebut bukan merupakan batas usia seseorang untuk bertindak, akan tetapi batas usia tersebut merupakan batas usia minimal seorang boleh melakukan pernikahan tersebut (dalam Walgito, 2000). Undang-Undang perkawinan dengan tegas menyatakan pria yang sudah mencapai umur 19 tahun dan wanita mencapai umur 16 tahun dapat dikatakan bahwa umur 
tersebut apabila dilihat dari segi fisiologisnya sudah matang dan dapat memberikan keturunan. Akan tetapi, jika dilihat dari segi psikologis masih belum bisa dikatakan dewasa, karena umur tersebut masih dikategorikan dalam remaja.

Badan Pusat Statistik (BPS) mengungkapkan angka pernikahan dini di Indonesia mengalami peningkatan dari 14,18\% pada tahun 2017 menjadi 15,66\% pada 2018. Peningkatan angka pernikahan dini menjadi catatan penting bagi pemerintah yang sedang berusaha melakukan memperbaiki Indeks Pembangunan Manusia (IPM). Hasil dari catatan BPS, provinsi dengan jumlah pernikahan muda tertinggi adalah Kalimantan Selatan sebesar 22,77\%, Jawa Barat sebesar 20,93\%, dan Jawa Timur sebesar 20,73\% (sindonews.com).

Dinas Pengendalian Penduduk dan Keluarga Berencana beberapa tahun lalu sudah melakukan pencegahan terhadap pernikahan dini di Kabupaten Malang, dan ternyata danpaknya tidak memunculkan sebuah perubahan. Kabupaten Malang menyampaikan pernikahan dini mengalami kenaikan jumlah setiap tahunnya. Tahun 2017 pernikahan dini memiliki 6.425 kasus, sedangkan tahun 2018 terjadi 4.272 kasus. Kementerian Agama (Kemenag) Kabupaten Malang menyatakan sudah tercatat data sejak tahun 2017 terdapat 240 kasus, untuk tahun 2018 menjadi 4.272 kasus. Pengadilan Agama (PA) Negeri Kabupaten Malang mengeluarkan data angka pernikahan dini lebih meningkat lagi. Pada tahun 2017 telah terjadi 377 pernikahan dini, serta meningkat lagi pada tahun 2018 menjadi 400. Data yang di ambil dilihat dari permohonan dispensasi yang diajukan pada Pengadilan Agama Malang (Malangtimes, 2019).

Permohonan dispensasi pernikahan merupakan peraturan untuk pasangan yang dibawah umur yang ingin melakukan pernikahan. Laki-laki memiliki umur dibawah 19 tahun dan perempuan dibawah 16 tahun. Peraturan tersebut diatur oleh Pasal 7 ayat 21974 Undang-Undang Pernikahan. Mengenai pelaksanaan Undang-Undang dalam pernikahan diatur pada Pasal 1 huruf b PP Nomor 9 tahun 1975. Pengadilan Agama (PA) Negeri Malang mengatakan permohonan dispensasi bisa dilakukan jika sudah memenuhi syarat usia laki-laki berumur 19 tahun dan perempuan 16 tahun. Kemudian Memiliki izin oleh kedua orang tua belah pihak. Apabila terjadi kecelakaan atau hamil diluar nikah, maka izin akan dilimpahkan ke Pengadilan Negeri Malang (Malangtimes, 2019).

Menurut Dlori (2005) pernikahan dini adalah perkawinan yang dilakukan pasangan dibawah umur yang kesiapan belum dikatakan maksimal seperti persiapan fisik, persiapan mental, juga persiapan materi. Pada umumnya penggolongan remaja dibagi menjadi tiga tingkatan yaitu remaja awal (11-15 tahun), remaja tengah (16-18 tahun), remaja akhir (19-21 tahun). Menurut Undang-Undang pernikahan, laki-laki yang menikah pada umur 19 tahun dikategorikan dalam perkembangan masa remaja tengah, sedangkan wanita yang berumur 16 tahun dikategorikan pada masa remaja awal. Olson, DeFrain, dan Skogrand (dalam Afiatin, 2018) menjelaskan bahwa perkawinan merupakan komitmen emosional dan legal dari dua orang berbagi keintiman emosional dan fisik, berbagi tugas, dan sumber-sumber ekonomi. 
Wisnuwardhani dan Mashoedi (dalam Afiatin, 2018) menyebutkan bahwa tahap perkawinan merupakan tahap yang penting dalam kehidupan karena terjadinya dua hal yaitu tawar-menawar identitas dan menegakkan batas-batas keluarga. Suami dan istri harus mengenali peranan yang dijalankan, artinya suami dan istri menyadari tentang statusnya sekarang. Seorang suami harus memperlakukan istrinya sebagai istri seperti memberikan nafkah, kasih sayang, begitu pula sebaliknya. Istri melayani suami, mempersiapkan makanan, mengurus rumah dan anak. Jika keduanya tidak menjalankan perannya dengan baik maka kedua belah pihak harus melakukan negosiasi tentang apa yang dilakukan. Selain itu yang harus dilakukan adalah menyediakan waktu lebih untuk memberikan perhatian pada pasangan, bertukar pendapat, dan kegiatan-kegiatan sehari-hari yang menjadi rutinitas.

Masa remaja merupakan masa topan-badai dan stress. Hal tersebut dikarenakan pada masa tersebut individu sedang mengalami masa pergolakan yang diwarnai konflik dan perubahan suasana hati G. Stanley Hall (dalam Santrock, 2012). Rosenblum dan Lewis (dalam Santrock, 2007) juga berpendapat bahwa, masa remaja merupakan suatu masa dimana mereka belum matang secara psikologisnya seperti fluktuasi emosi yang sering terjadi (emosi naik dan turun) berlangsung lebih sering.

Pada tahap perkembangan kognitif Carol dan David (dalam Desmita, 2006) menjelaskan bahwa remaja memiliki kemampuan memahami pemikirannya sendiri dan pemikiran orang lain. Remaja membayangkan apa yang dipikirkan orang lain dengannya, remaja memiliki kemampuan merumuskan perencanaan yang strategis, kemampuan mengambil keputusan. Menurut Santrock (dalam Desmita, 2006) remaja yang lebih tua lebih berkompenten dari pada remaja yang lebih muda dalam pengambilan keputusannya. Remaja yang lebih tua cenderung menghasilkan pilihanpilihan, mengantisipasi akibat dari keputusannya. Akan tetapi, pada remaja yang lebih muda memiliki kemampuan yang kurang dalam kerampilan pengambilan keputusannya. Myers (dalam Desmita, 2006) menyatakan penalaran yang dimilikinya, menjadikan remaja mampu membuat pertimbangan dan melakukan perdebatan sekitar topik-topik abstrak tentang manusia, kebaikan dan kejahatan, kebenaran dan keadilan. Ketika kemampuan penalaran dalam remaja berkembang memberikan suatu tingkatan pertimbangan moral dan sosial yang baru. Santrock (2012) berpendapat bahwa remaja memiliki egosentris yang suka menilai dirinya sendiri tanpa melihat pandangan orang lain tentang diri mereka, krisis identitas juga terjadi pada masa remaja ini, dimana berdampak remaja cenderung menarik diri dan kehilangan identitasnya dikerumunan. Walgito (2000) juga berpendapat usia remaja umumnya belum mempunyai pegangan dalam hal sosial ekonomi. Berdasarkan penjelasan diatas dapat disimpulan kematangan psikologis yang belum tercapai mendorong terjadinya percekcokan atau konflik ketika remaja tersebut memasuki kehidupan pernikahan.

Perbedaan gender pada wanita dan pria memiliki perkembangan yang sangat berbeda. Menurut pendapat Ekawati dan Wulandari (2011) perempuan lebih tertarik pada masalah-masalah kehidupan yang konkrit, sedangkan laki-laki lebih tertarik pada segi-segi yang abstrak. Perempuan dalam fungsi sosial lebih sering memaknai 
suatu peristiwa dibandingkan dengan laki-laki dan suka mengembangkan relasi dengan orang lain. Perempuan cenderung untuk memikirkan suasana hati yang dialaminya dan membesar-besarkannya. Sedangkan pria sering kali bersikap dominan, sangat kuat, agresif, dan suka mengontrol wanita (Santrock, 2012).

Dikehidupan berumah tangga pasti tidak luput dengan permasalahanpermasalahan. Salah satu faktor penyebab utama adalah pasangan-pasangan yang belum dewasa. Walgito (2000) menjelaskan bahwa perkawinan yang masih terlalu muda banyak mengundang masalah yang tidak diharapkan. Hal tersebut dikarenakan segi psikologis mereka belum matang, seperti cemas, cemas yang dimaksud adalah perasaan ketakutan dan kekhawatiran dalam menghadapi masalahmasalah yang timbul dalam pernikahannya dan stress seperti tekanan, desakan atau respon emosional, contohnya, merencanakan pernikahan, mengurus keluarga.

Santrock (2012) menjelaskan bahwa kehidupan pernikahan adalah masuknya individu kedalam lima tahapan siklus kehidupan keluarga, yaitu dengan persiapan meninggalkan rumah sebagai individu yang mandiri dan bertanggungjawab, finansial dan psikologis. Banyak pasangan yang menikah namun tidak melakukan persiapan pertanggung jawaban pribadi saat menikah dan berkeluarga secara baik. Hal tersebut dapat mempengaruhi kepuasan pernikahan dari pasangan. Ketika remaja laki-laki yang berumur 19 dan wanita berumur 16 menikah, apabila terjadi sebuah konflik atau perbedaan pandangan pada pernikahannya mereka akan sulit menyelesaikannya karena tahap perkembangan emosinya masih naik turun. Remaja muda yang menikah juga sulit dalam mengambil keputusan, serta egosentris yang ada dalam diri remaja tersebut (dalam Hermawan, 2010).

Semua pasangan suami-istri menginginkan kepuasan dalam pernikahannya. Kepuasan pernikahan adalah perasaan subjektif yang dialami oleh pasangan suami istri yang berdampak terhadap pasangan untuk mengungkapkan rasa saling menghargai dan mencintai satu sama lain, sehingga ia dapat menggambarkan presepsinya tentang kelemahan dan kelebihan dalam pernikahannya. Hal ini juga didukung dengan kognitif pada remaja, mereka mampu memahami dirinya dan memahami pasangannya. Selain itu mereka juga bisa membanyangkan apa yang dipikirkan pasangannya terhadap dirinya. Perkembangan kognitif yang ada pada remaja tersebut, berdampak pada pernikahan remaja dalam memahami pemikiran pasangannya dengan menghargai kelemahan dan kelebihan dari pasangannya tersebut. Kepuasan itu muncul jika aspek-aspek dalam kepuasan pernikahan itu muncul, seperti (1) dapat memberikan masukan perilaku postif dan negatif pasangan; (2) dapat mengekspresikan perasaan emosional; (3) memberikan sentuhan-sentuhan fisik, berciuman, berpelukan, dan melakukan hubungan seks; (4) menuntut perubahan perilaku pada pasangan; (5) memberikan dukungan sosial terhadap pasangan seperti perhatian dan rasa aman; (6) tidak melakukan kekerasan pada pasangan. Kepuasan dalam perkawinan bagi semua pasangan suami istri merupakan suatu hal penting dalam perjalanan suatu perkawinan. Adanya kepuasan perkawinan, 
mengakibatkan pasangan suami istri akan menumbuhkan sebuah komitmen dalam kehidupan berumah tangganya (Stone dan Shackelford, 2007).

Adanya ketidakpuasan dalam pernikahan dapat menyebabkan konflik dalam pernikahan seperti perselihan perbedaan pendapat, serta tekanan psikologi seperti depresi dan cemas. Selain itu, dalam pernikahan banyak timbul perselisihan yang berkepanjangan antar pasangan dan tidak diatasi dengan baik. Hal ini adalah salah satu pemicu perceraian. Ketidakpuasan pernikahan merupakan masalah utama terjadinya perceraiaan (Amanto, Booth, Johnson, danRogers, 2007). Pada tahun 2017, Pengadilan Agama (PA) Kabupaten Malang menerima 5.377 perkara cerai, sedangkan tahun 2018 ada sekitar 8.904, dan untuk tahun 2019 ada 2.744 perkara perceraian (pamalangkab.go.id, 2019).

Penelitian yang dilakukan Bradbury dan Lavner (2012), pasangan yang tidak memiliki kepuasan pada pernikahanya, mudah mengalami konflik yang akan berdampak pada perceraian. Terdapat pula penelitian tentang hubungan suami istri yang menjelaskan tidak semua pasangan mengalami kesulitan yang akan menyebabkan tekanan, tingkat stres, serta kecemasan dalam pernikahannya akan tetapi akan berpengaruh terhadap keluarganya.

Kehidupan dalam pernikahan akan muncul berbagai masalah yang akan mempengaruhi keharmonisan dalam rumah tangga. Permasalahan tersebut bisa dipecahkan jika pola interaksi dalam pernikahan itu baik, dan pola interaksi tersebut membutuhan komunikasi didalamnya. Perkembangan bahasa usia remaja dapat terus meningkat perbendaharaan kata, mereka mengalami perubahan gaya bahasa, dan semakin lancar dan fasih dalam berkomunikasi. Keterampilan dan performansi tata bahasa terus berkembang ke arah tercapainya kompetensi berbahasa secara lengkap sebagi wujud dari kompetensi komunikasi (Ali dan Asrori, 2012).

Ayub (2010) menyatakan bahwa komunikasi adalah satu faktor penting dalam terciptanya kepuasan perkawinan. Pendapat tersebut juga didukung oleh pendapat Duvval dan Miller (1985), kemampuan berkomunikasi yang baik merupakan faktor pendukung terciptanya kepuasan pernikahan. Penelitian yang dilakukan esere (2008) menunjukan bahwa salah satu faktor penting untuk stabilitas perkawinan adalah peran komunikasi yang efektif. Pasangan yang menikah harus berusaha untuk selalu duduk bersama dan membiarkan perbedaan mereka. Studi eksperimen Vilani (1985), ketika komunikasi pasangan tersebut buruk maka akan menyebabkan kegagalan dalam pernikahan. Komunikasi bertujuan untuk memahami satu sama lain dalam kehidupan sosial dan cara berpikir. Komunikasi memiliki peran penting dalam hubungan pernikahan yang dapat menuntun berkembangnya suatu hubungan dan tercapainya kepuasan dalam pernikahan. Ketidakpuasan pernikahan akan menyebabkan kegagalan dalam pernikahan.

Hasil penelitian yang didapati oleh Batool dan Khalid (2012), menyatakan bahwa pernikahan yang sehat bukan berarti pernikahan yang tidak mengalami konflik, melainkan bagaimana cara pasangan suami istri mencari jalan keluar yang efektif untuk permasalahan yang mereka alami. Sejalan dengan penelitian Thomas (dalam Batool dan Khalid, 2012), penyelesaiaan yang efektif dapat membawa ketenangan 
saat terjadi konflik dan perbedaan presepsi, serta dapat bersikap jujur apa adanya dan saling membantu satu sama lain. Perkembangan bahasa yang dimiliki remaja ketika menikah sudah baik. Hal tersebut dapat dilihat dari tahap perkembangannya. Ketika terjadi sebuah konflik dalam pernikahan yang berpengaruh terhadap kepuasan pernikahan, nantinya pasangan remaja tersebut dapat mengkomunikasikan dengan efektif seperti yang ada didalam komunikasi efektif, dimana penerima informasi dapat memahami apa yang disampaikan oleh pemberi informasi.

Komunikasi yang baik adalah komunikasi yang efektif. Canary dan Stanfford (2002), merupakan sebuah tindakan atau kegiatan untuk menjaga hubungan sesuai dengan yang diinginkan. Hal tersebut melibatkan perilaku yang strategis dan rutin yang terdiri dari komunikasi langsung dan komunikasi tidak langsung. Tujuan dari komunikasi efektif adalah terciptanya keberhasilan dan hubungan yang saling memahami satu sama lain. Witkins dan Rose (1981) mengatakan bahwa saling memahami satu sama lain dapat membentuk dasar yang memuaskan antar pasangan. Menurut Esere (2014), komunikasi dalam pernikahan membutuhkan komunikasi yang tulus, jujur, ikut merasakan apa yang dirasakan oleh pasangan. Menurutnya, terdapat beberapa solusi dan saran dalam komunikasi efektif pernikahan diantara lainnya adalah percaya pada pasangan, mempertimbangkan pendapat pasangan saat melakukan diskusi, mempertimbangkan kontribusi pada pasangan seperti suami/istri ikut serta dalam suatu kegiatan atau pemecahkan masalah dalam pernikahan agar tercapainya suatu tujuan yang sukses.

Rumusan masalah yang akan diangkat dalam penelitian ini yaitu apakah komunikasi efektif dapat berpengaruh terhadap kepuasan pernikahan pada pasangan yang menikah dini. Tujuan penelitian ini adalah untuk mengetahui pengaruh komunikasi efektif terhadap kepuasan pernikahan pada pasangan yang menikah dini. Manfaat teoritisnya diharapkan penelitian ini dapat berkontribusi dalam bidang ilmu psikologi khususnya pada pasangan yang menikah dini yang berhubungan dengan komunikasi efektif terhadap kepuasan pernikahan. Manfaat praktisnya, diharapkan penelitian ini dapat memberikan pengetahuan kepada pasangan yang menikah dini bahwasanya komunikasi efektif jika diterapkan dalam kehidupan rumah tangga dapat meningkatkan kepuasan pernikahan.

\section{METODE}

\section{Rancangan Penelitian}

Pendekatan yang digunakan dalam penelitian ini yaitu pendekatan kuantitatif metode non-eksperimen. Metode kuantatif merupakan metode penelitian tradisional karena metode ini sudah cukup lama digunakan sehingga sudah mentradisi sebagai metode untuk penelitian. Pendekatan kuantitatif banyak menggunakan angka-angka dari mulai pengumpulan data, penafsiran terhadap data, serta penampilan dari hasilnya (Sugiyono, 2017). Jenis penelitian yang digunakan adalah, dimana penelitian tersebut digunakan untuk melakukan prediksi, bagaimana nilai variabel dependen 
mengalami perubahan bila nilai variabel independen dinaikan atau diturunkan nilainya.

\section{Subjek Penelitian}

Teknik pengambilan subjek dalam penelitian ini menggunakan purposive sampling yaitu merupakan teknik penentuan sampel dengan pertimbangan tertentu dengan kriteria dan populasi yang ditentukan oleh peneliti (Sugiyono, 2017). Jumlah sampel yang akan dipakai dalam penelitian ini adalah berjumlah 100 responden pasangan yang menikah dini. Subjek penelitian ini adalah pasangan yang menikah dini di kota Malang dengan kriteria, yaitu:

1. Pasangan yang menikah maksimal diumur 19 tahun (laki-laki) dan 16 tahun (wanita).

2. Tinggal serumah tidak memiliki hubungan jarak jauh dengan pasangannya.

3. Bertempat tinggal didaerah Malang, Jawa Timur.

\section{Variabel dan Instrumen Penelitian}

Terdapat dua variabel dalam penelitian ini yaitu variabel bebas $(X)$ dan variabel terikat (Y). Variabel bebas dalam penelitian ini adalah komunikasi efektif. Komunikasi efektif adalah suatu kegiatan memberikan sebuah informasi kepada pasangan, sehingga membuat pasangan memahami isi dari informasi yang disampaikan yang bertujuan untuk mempertahankan sebuah hubungan didalamnya. Informasi tersebut mencakup komunikasi verbal dan non verbal. Sedangkan variabel terikatnya adalah kepuasan pernikahan. Kepuasan pernikahan adalah perasaan subjektif yang dirasakan pasangan suami istri, seperti perasaan yang bahagia, memiliki kepuasan, pengalaman menyenangkan yang berdampak pada kemampuan menunjukan perasaan saling menghargai satu sama lain dan menyayangi antar pasangan suami/istri agar terhindar dari suatu konflik.

Instrumen penelitian yang gunakan untuk mengukur komunikasi efektif adalah skala ukur yang digunakan berdasarkan teori yang dibuat Canary dan Stafford (2002) sebanyak 5 aspek yang kemudian ditambahkan Canary dan Zelley (dalam Punyanunt Carter, 2004) sebanyak 2 aspek sehingga total aspek komunikasi efektif yang digunakan sebanyak 7 aspek terdiri dari 1) positivity (sopan, baik dan menyenangkan), 2) opennes (mampu mengungkapkan pikiran dan perasaan), 3) assurance (bertanggung jawab terhadap peran sebagai suami istri), 4) social networking (menjalin hubungan yang harmonis dengan pasangan dan keluarga), 5) sharing task (membantu satu sama lain dalam menjalankan peran sebagai suami istri), 6) conflict management (menyelesaikan masalah secara bersama), dan 7) advice (memberikan dan menjalankan nasehat yang disampaikan oleh pasangan). Ciri-ciri komunikasi efektif adalah sopan, baik, menyenangkan, dan bertanggungjawab. Skala dalam penelitian ini adalah skala komunikasi efektif yang merupakan adaptasi dari penelitian yang dilakukan oleh Atiqoh (2014). Skala ini memiliki 14 item dengan validitas 0,024.

Selanjutnya instrumen penelitian yang digunakan untuk mengukur kepuasan pernikahan adalah skala ukur yang digunakan berdasarkan teori Bradbury, Fincham, 
dan Beach (2002) yang terdiri dari 1) cognition (menerima perilaku negatif pasangan); 2) affect (mengekspresikan perasaan emosional terhadap pasangan agar bisa melihat pernikahan dari waktu-kewaktu); 3) physiology (melakukan hubungan seksual; 4) patterns (menjaga hubungan tetap baik walaupun ada perilaku yang tidak diinginkan); 5) social support (dukungan sosial berupa perhatian, kebutuhan fisik dan finansial); 6) violence (meminimalisir kekerasan dalam rumah tangga). Kepuasan pernikahan diukur menggunakan skala adaptasi dari penelitian Humaira (2018). Skala ini memiliki 36 item dengan reliabilitas 0,884.

Instrumen yang digunakan pada kedua skala ini menggunakan skala linkert. Terdapat item yang mendukung penelitian (favorable) dan item yang tidak mendukung penelitian (unfavorable). Pada skala ini terdiri 4 pilihan jawaban yakni: sangat setuju (SS), setuju (S), tidak setuju (TS), sangat tidak setuju (STS). Untuk item yang mendukung (favorable) diberikan skor 4 untuk pilihan jawaban sangat setuju (SS), skor 3 untuk pilihan jawaban setuju (S), skor 2 untuk pilihan jawaban tidak setuju (TS), skor 1 untuk pilihan jawaban sangat tidak setuju (STS). Sedangkan untuk item yang tidak mendukung (unfavorable) akan diberi skor 1 pada jawaban sangat setuju (SS), skor 2 pada jawaban setuju (S), skor 3 pada jawaban tidak setuju (TS), skor 4 pada jawaban sangat tidak setuju (STS).

Skala komunikasi efektif dan kepuasan pernikahan setelah dilakukan uji coba didapatkan hasil untuk skala komunikasi efektif dari 14 item 1 item yang tidak valid, sehingga tersisa13 item valid yang akan digunakan untuk penelitian pada 100 pasangan yang melakukan pernikahan dini. Sedangkan skala kepuasan pernikahan yang berjumlah 36 item terdapat 7 item yang tidak valid dan tersisa 29 item. Nilai validitas komunikasi efektif berkisar dari 0,211-0,578 dengan nilai reliabilitas sebesar 0,835 . Selanjutnya nilai validitas kepuasan pernikahan berkisar 0,001-0,697 dengan nilai reliabilitas 0,887 .

\section{Prosedur dan Analisa Data Penelitian}

Terdapat 3 tahap dalam prosedur penelitian yang akan digunakan peneliti, yaitu tahap persiapan, tahap pelaksanaan, dan tahap analisis. Pertama-tama peneliti akan melakukan tahap persiapan dengan mencari fenomena terlebih dahulu serta mencari rumusan masalah dari fenomena tersebut kemudian barulah menentukan variabel penelitian yang akan digunakan, selanjutnya peneliti mencari teori yang sesuai dengan variabel penelitian, peneliti menentukan skala komunikasi efektif dan kepuasan pernikahan untuk penelitian. Menetapkan lokasi untuk penelitian. Sebelum melakukan penelitian peneliti mencari skala yang sesuai, peneliti melakukan uji coba skala komunikasi efektif dan skala kepuasan pernikahan dengan subjek pasangan yang menikah dini dengan kriteria laki-laki berumur 19 tahun dan perempuan 16 tahun yang bertempat tinggal di kota Malang. Data skala yang sudah didapat kemudian peneliti melakukan analisis untuk mengetahui item valid dan item tidak valid. Uji coba skala dilakukan tanggal 26 juni 2019 sampai 2 juli 2019 kepada 60 
pasangan yang menikah dini di Kota Malang. Peneliti melakukan uji coba skala dengan menyebar secara langsung sesuai dengan kriteria yang peneliti tentukan.

Tahap pelaksanaan. Peneliti menyebarkan skala pada pasangan yang menikah dini sesuai dengan kriteria yang sudah ditentukan yang bertempat tinggal di kota Malang. Pengambilan data penelitian dilakukan pada tanggal 11 juli sampai 11 agustus kepada 100 pasangan yang menikah dini di Desa Singosari Kota Malang.

Tahap analisis data. Menganalisis data yang sudah didapatkan setelah menyebar skala. Kemudian data tersebut diinput dan diolah dengan program analisi statistik SPSS 21 yang menggunakan analisis regresi linear sederhana. Setelah itu data dikaitkan dengan teori sehingga dapat menarik kesimpulan dari skripsi.

\section{HASIL}

Subjek penelitian ini terdiri dari 100 subjek pasangan yang melakukan pernikahan dini, dengan rentang usia laki-laki 14-19 tahun dan perempuan 14-16 tahun yang bertempat tinggal di Desa Singosari Kabupaten Malang. Peneliti membatasi usia untuk laki-laki 19 tahun dan perempuan 16 tahun dikarenakan berdasarkan Undang-Undang perkawinan No. 1 tahun 1974 pasal 7. Subjek dalam penelitian ini apabila dilihat berdasarkan jenis kelamin dan usia dapat dilihat pada able 1 berikut:

Tabel 1. Deskripsi Subjek Penelitian

\begin{tabular}{ccc}
\hline Kategori & $\begin{array}{c}\text { Jumlah } \\
\text { Subjek }\end{array}$ & Presentase \\
\hline Jenis Kelamin & & \\
Laki-laki & 50 & $50 \%$ \\
Perempuan & 50 & $50 \%$ \\
\hline Usia & & \\
Laki-laki & & $0 \%$ \\
14 tahun & 0 & $12 \%$ \\
15 tahun & 6 & $16 \%$ \\
16 tahun & 8 & $28 \%$ \\
17 tahun & 14 & $10 \%$ \\
18 tahun & 5 & $34 \%$ \\
19 tahun & 17 & $12 \%$ \\
Perempuan & & $34 \%$ \\
14 tahun & 6 & $54 \%$ \\
15 tahun & 17 & \\
16 tahun & 27 & $\mathbf{1 0 0} \%$ \\
\hline Total & & \\
\hline
\end{tabular}


Berdasarkan tabel 1, didapati hasil 100 orang yang mernikah dini, untuk suami sebanyak 6 orang memiliki usia 15 tahun, 8 orang memiliki usia 16 tahun, 14 orang memiliki usia 17 tahun, 5 orang memiliki usia 18 tahun, 17 orang memiliki usia 19 tahun. Sedangkan untuk istri sebanyak 6 orang memiliki usia 14 tahun, 17 orang memiliki usia 15 tahun, 27 orang memiliki usia 16 tahun. Kemudian peneliti ingin melihat tinggi dan rendahnya komunikasi efektif serta kepuasan pernikahan dilihat dari jenis kelamin subjek. Berikut data yang didapatkan:

Tabel 2. Komunikasi Efektif dan Kepuasan Pernikahan dilihat dari Jenis Kelamin

\begin{tabular}{ccc}
\hline Kategori & Laki-Laki (Suami) & Perempuan (Istri) \\
\hline Komunikasi Efektif (X) & & \\
Tinggi & $31 \%$ & $24 \%$ \\
Rendah & $19 \%$ & $26 \%$ \\
Total & $50 \%$ & $50 \%$ \\
Kepuasan Pernikahan (Y) & & \\
Tinggi & $21 \%$ & $32 \%$ \\
Rendah & $29 \%$ & $18 \%$ \\
Total & $50 \%$ & $50 \%$ \\
\hline
\end{tabular}

Berdasarkan tabel 2, dapat dilihat bahwa rata-rata suami memiliki komunikasi efektif yang baik (tinggi). Sedangkan rata-rata istri memiliki komunikasi yang kurang baik (rendah). Hal ini berbanding terbalik pada kepuasan pernikahan, rata-rata istri memiliki kepuasan pernikahan yang baik (tinggi). Sedangkan suami rata-rata memiliki kepuasan pernikahan yang kurang baik (rendah). Kemudian peneliti ingin melihat tinggi rendahnya komunikasi efektif dan kepuasan pernikahan jika dilihat dari usia subjek. Berikut data yang didapatkan.

Tabel 3. Uji Beda Komunikasi Efektif dilihat dari Jenis Kelamin

\begin{tabular}{|c|c|c|c|c|c|c|}
\hline \multicolumn{7}{|c|}{ Komunikasi Efektif } \\
\hline $\begin{array}{l}\text { Jenis } \\
\text { Kelamin }\end{array}$ & Kategori & Frekuensi & Persentase & Mean & S.D & Sig. \\
\hline \multirow{3}{*}{ Laki-laki } & Tinggi & 31 & $62 \%$ & \multirow{3}{*}{42,58} & \multirow{3}{*}{3,423} & \multirow{6}{*}{0,463} \\
\hline & Rendah & 19 & $38 \%$ & & & \\
\hline & Total & 50 & $100 \%$ & & & \\
\hline \multirow[t]{3}{*}{ Perempuan } & Tinggi & 24 & $48 \%$ & \multirow{3}{*}{43,16} & \multirow[t]{3}{*}{4,391} & \\
\hline & Rendah & 26 & $52 \%$ & & & \\
\hline & Total & 50 & $100 \%$ & & & \\
\hline
\end{tabular}

Berdasarkan tabel 3, dilihat bahwa komunikasi efektif kategori tinggi pada lakilaki sebanyak 31 orang, untuk kategori rendah sebanyak 19 orang. Sedangkan komunikasi efektif kategori tinggi pada perempuan sebanyak 24 orang dan kategori 
rendah sebanyak 26 orang. Dalam komunikasi efektif laki-laki dan perempuan tidak menunjukan adanya perbedaan dilihat dari nilai Sig. dibawah 0,05 adalah 0,463. Selanjutnya akan diuji beda kepuasan pernikahan pada laki-laki dan perempuan dengan hasil berikut:

Tabel 4. Uji Beda Kepuasan Pernikahan dilihat dari Jenis Kelamin

\begin{tabular}{|c|c|c|c|c|c|c|}
\hline \multicolumn{7}{|c|}{ Kepuasan Pernikahan } \\
\hline Jenis Kelamin & Kategori & Frekuensi & Persentase & Mean & S.D & Sig. \\
\hline \multirow[t]{3}{*}{ Laki-laki } & Tinggi & 15 & $30 \%$ & \multirow{3}{*}{94,90} & \multirow{3}{*}{7,622} & \multirow{6}{*}{0,014} \\
\hline & Rendah & 35 & $70 \%$ & & & \\
\hline & Total & 50 & $100 \%$ & & & \\
\hline \multirow[t]{3}{*}{ Perempuan } & Tinggi & 32 & $64 \%$ & \multirow{3}{*}{90,98} & \multirow{3}{*}{8,027} & \\
\hline & Rendah & 18 & $36 \%$ & & & \\
\hline & Total & 50 & $100 \%$ & & & \\
\hline
\end{tabular}

Berdasarkan tabel 4, dilihat bahwa komunikasi efektif kategori tinggi pada lakilaki sebanyak 15 orang, untuk kategori rendah sebanyak 35 orang. Sedangkan komunikasi efektif kategori tinggi pada perempuan sebanyak 32 orang dan kategori rendah sebanyak 18 orang. Ada perbedaan dalam kepuasan pernikahan laki-laki dan perempuan dengan nilai Sig. dibawah 0,05 adalah 0,014. Selanjutnya akan diuji pengaruh komunikasi efektif terhadap kepuasan pernikahan:

Tabel 5. Pengaruh Komunikasi Efektif terhadap Kepuasan Pernikahan

\begin{tabular}{ccccc}
\hline \multirow{2}{*}{ Kategori } & \multicolumn{4}{c}{ Kepuasan Pernikahan } \\
& $\boldsymbol{r}$ & $\boldsymbol{r}^{2}$ & $\boldsymbol{F}$ & $(\boldsymbol{p})$ sig \\
\hline Komunikasi Efektif & 0,391 & 0,153 & 17,685 & 0,000 \\
\hline
\end{tabular}

Berdasarkan hasil analisis regresi linear sederhana dari tabel 2 menunjukkan besarnya $F$ sebesar 17,685 dan nilai $p=0.000<0.05$, artinya hipotesis diterima yaitu terdapat pengaruh komunikasi efektif terhadap kepuasan pernikahan. Hal tersebut bisa dilihat pada nilai $\mathrm{r}=0,391$ dan nilai ${ }^{2}$ sebesar 0,153 . Hal ini berarti $15,3 \%$ kepuasan pernikahan dipengaruhi oleh komunikasi efetif pada pasangan yang melakukan pernikahan dini. Artinya $84,7 \%$ kepuasan pernikahan dipengaruhi oleh faktor lain diluar komunikasi efektif.

\section{DISKUSI}

Berdasarkan hasil uji regresi linear sederhana yang telah dilakukan menunjukkan bahwa komunikasi efektif adalah salah satu faktor yang memperngaruhi kepuasan pernikahan pada pasangan yang melakukan pernikahan dini, yakni sebesar 15,3\% kemudian untuk 84,7\% dipengaruhi oleh faktor-faktor lain. Hal ini didukung penelitian Rahmi (2011) terdapat hubungan positif pada dukungan sosial dan kepuasan pernikahan sebesar 56,1 \%. Didukung penelitian yang 
dilakukan oleh Nurmaya (2016) menunjukkan terdapat hubungan yang positif dan signifikan antara komunikasi efektif dan kepuasan pernikahan sebesar 83,8 \%.

Penelitian yang dilakukan oleh Soraiya, Khairani, Rachmatan, Sari, dan Sulistyani (2016) mengakatan faktor-faktor lain yang mempengaruhi kepuasan pernikahan selain komunikasi efektif yaitu masa kanak-kanak, pendidikan, kehidupan seksual, tingkat kesetaraan, dan ekspresi kasih sayang sebesar 85,83\%. Seperti penelitian lainnya yang dilakukan Rosen-Grandon, Myers, dan Hattie, (2004) pasangan yang menikah dapat merasakan kepuasan dalam pernikahannya jika dapat saling berkomitmen, setia, memiliki nilai moral yang kuat, menghargai pasangan sebagaimana kita menghargai teman, berkomitmen dalam hubungan seksual, ingin menjadi orang tua yang baik untuk anak-anaknya dan beriman kepada Tuhan, selalu ingin bersikap menyenangkan untuk pasangan, dan keinginan untuk memaafkan dan dimaafkan.

Menurut Bagwell (2006) hubungan dalam pernikahan dapat dikatakan harmonis jika pasangan memiliki sikap yang terampil dalam menghadapi permasalahan yang ada dalam pernikahanya, dapat mengontrol emosi dan menghadapi setiap masalah yang timbul dan tidak menghindarinya. Pernikahan yang stabil memerlukan sebuah kemampuan dalam mengkomunikasikan pikiran dan perasaan secara efektif serta kemampuan pasangan dalam mengatasi ketegangan yang ada. Menurut Snyder (1997) salah satu aspek dalam kepuasan perkawinan adalah komunikasi yang efektif dimana individu dapat membicarakan berbagai permasalahan dengan pasangannya sehingga berdampak pada kepuasan pernikahan. Komunikasi yang efektif dilakukan denhan melihat pemahaman yang diungkap oleh pasangan sehingga terjadi peningkatan kepuasan pernikahan.

Apabila dilihat dari hasil uji beda komunikasi efektif, tidak terdapat perbedaan komunikasi efektif suami dan istri. Perkembangan bahasa yang dimiliki remaja ketika menikah sudah baik. Hal tersebut dapat dilihat dari tahap perkembangannya. Ketika terjadi sebuah konflik dalam pernikahan yang berpengaruh terhadap kepuasan pernikahan, nantinya pasangan remaja tersebut dapat mengkomunikasikan dengan efektif seperti yang ada didalam komunikasi efektif, dimana penerima informasi dapat memahami apa yang disampaikan oleh pemberi informasi. Devito (2011), berkomunikasi secara efektif akan dilihat pada lima aspek komunikasi, yaitu terdapat rasa saling jujur apa adanya, merasakan apa yang dirasakan oleh orang lain, dukungan sosial, sikap yang menyenangkan, dan kesamaan satu sama lain. Kegagalan berkomunikasi menurut Rakhmat (2000) dikatakan juga sebagai komunikasi yang tidak efektif. Hal ini berarti gagasan yang disampaikan tidak mudah dipahami, menjengkelkan dan menciptakan jarak yang semakin jauh dengan orang lain serta gagal memberi dorongan orang lain untuk bertindak. Pernikahan usia remaja yang belum siap untuk melakukan pernikahan.

Hal ini berbanding terbalik dengan hasil uji beda kepuasan pernikahan pada suami dan istri. Terdapat perbedaan kepuasan pernikahan suami dan istri. Istri sering merasa jenuh atau bosan dalam mengurus rumah, anak, dan suami. Bahkan 
suami pun enggan bertukar atau membantu tugas istri. Istri tetap mengalami kepuasan pada pernikahannya. Menurut pendapat Ekawati dan Wulandari (2011) perempuan lebih tertarik pada masalah-masalah kehidupan yang konkrit, sedangkan laki-laki lebih tertarik pada segi-segi yang abstrak. Perempuan dalam fungsi sosial lebih sering memaknai suatu peristiwa dibandingkan dengan laki-laki dan suka mengembangkan relasi dengan orang lain. Perempuan cenderung untuk memikirkan suasana hati yang dialaminya dan membesar-besarkannya. Sedangkan pria sering kali bersikap dominan, sangat kuat, agresif, dan suka mengontrol wanita (Santrock, 2012). Hasil penelitian yang dilakukan oleh Srisusanti dan Zulkaida (2013), mengatakan bahwa faktor yang cukup mempengaruhi kepuasan pernikahan pada istri yaitu komunikasi. Hal ini terjadi jika suami atau istri berkerja mereka akan membicarakan banyak hal satu sama lain. Secara psikologis laki-laki rentan susah mengontrol emosi saat menyelesaikan konflik dibandingkan perempuan sehingga hal tersebut dapat mempengaruhi kepuasan pernikahan suami. Penelitian lain juga dilakukan oleh Tiara dan Qudsyi (2018), Tidak ditemukannya perbedaan kepuasan pernikahan ditinjau dari usia, pendidikan terakhir, jumlah anak, usia pernikahan dan pekerjaan responden, hal ini bisa terjadi jika terdapat beberapa faktor lain yang dapat mempengaruhi kepuasan pernikahan pada istri.

Pada usia yang bisa dikatakan masih remaja, mulailah timbul masa peralihan dari masa remja ke masa dewasa yang mencari jati diri. Dilihat dari segi psikologis ketika remaja menikah akan rentan mengalam konflik yang berujung pada perceraia. Hal tersebut terjadi karena belum siapnya mental dari remaja tersebut. Penelitian yang dilakukan Weinstein, Powers dan Laverghetta (2010), usia berpengaruh saat melakukan pernikahan yang pertama kali terhadap kepuasan pernikahan yang dirasakan oleh pasangan tersebut. Usia pernikahan yang terbilang masih muda belum memiliki kesiapan secara matang, fisik, psikologis maupun mental berdampak terhadap kepuasan pernikahan yang dijalaninya. Lee (dalam Alder, 2010), mereka yang menikah muda mungkin akan mengalami kebingungan dalam melaksanakan peran sebagai suami/istri. Menurut Kerkmann, Lee, Lown, dan Allgood (2000), komunikasi yang tidak jujur dan penyesuaian pernikahan kurang baik akan timbul ketidakpuasan dalam pernikahan.

Hal ini berbanding terbalik dengan hasil kepuasan pernikahan istri memiliki skor lebih tinggi dibandingkan dengan suami. Dilihat dari skor mean istri sebesar 94,900 dan mean suami 90,980. Walaupun istri sering merasa jenuh atau bosan dalam mengurus rumah, anak, dan suami. Bahkan suami pun enggan bertukar atau membantu tugas istri. Istri tetap mengalami kepuasan pada pernikahannya bahkan dilihat dari hasil penelitian yang dilakukan oleh Srisusanti dan Zulkaida (2013), mengatakan bahwa faktor yang cukup mempengaruhi kepuasan pernikahan pada istri yaitu komunikasi. Hal ini terjadi jika suami atau istri berkerja mereka akan membicarakan banyak hal satu sama lain. Penelitian lain juga dilakukan oleh Tiara dan Qudsyi (2018), Tidak ditemukannya perbedaan kepuasan pernikahan ditinjau dari usia, pendidikan terakhir, jumlah anak, usia pernikahan dan pekerjaan 
responden, hal ini bisa terjadi jika terdapat beberapa faktor lain yang dapat mempengaruhi kepuasan pernikahan pada istri.

Terdapat faktor-faktor tertentu yang dapat meningkatkan kepuasan menurut Sprunt dan Howes dalam (Atta, 2013) yaitu kesetaraan, timbal balik hubungan, saling memberi dan menerima, menjadi saling terlibat dalam urusan karir, memiliki komitmen yang sama, dan berlatih mengambil keputusan yang sama bahkan berbagi sikap dalam peran seksualitas, serta pada pasangan non-tradisonal justru suami memiliki tinggi kepuasan yang lebih tinggi. Sebelumnya berbeda dengan penelitian Paputungan (2012) menyatakan suami merasa kuranng puasa dalam hal keintiman fisik, sepertinya hal tersebut dapat dicegah dengan adanya kesetaraan sehingga suami merasa ada hubungan timbal balik yang menguntungkan.

Dilihat tabel 3, usia subjek pasangan yang melakukan pernikahan dini, usia rentang 15 dan 18 memiliki komunikasi efektif yang tinggi. Sedangkan rentang usia 14, 16, dan 19 memiliki komunikasi yang rendah. Hal ini didukung oleh pendapat Darajat (1992) komunikasi efektif merupakan bagian dari unsur kepribadian remaja. Keadaan tersebut lebih lanjut akan dapat berfungsi sebagai kendali diri dan perilaku dalam menghadapi segala keinginan dan dorongan yang timbul termasuk menghadapi masalah. Komunikasi harus dilakukan secara efektif agar komunikasi itu dapat mudah dimengerti oleh komunikan, komunikasi yang efektif dapat dilakukan apabila seseorang yang berkomunikasi memahami tentang pengertian dari komunikasi efektif, proses komunikasi efektif dan unsur-unsur komunikasi efektif. Menurut Rakhmat (2008) menyebutkan, komunikasi yang efektif ditandai dengan adanya pengertian, dapat menimbulkan kesenangan, mempengaruhi sikap, meningkatkan hubungan sosial yang baik, dan pada akhirnya menimbulkan suatu tindakan.

Apabila dilihat dari hasil yang sudah didiskusikan bahwa usia 15 dan 17 digolongkan pada usia remaja awal yang menikah diusia muda dan memiliki kepuasan pernikahan yang tinggi. Selain itu usia 14, 16, dan 18 juga tergolong pada usia remaja awal yang memiliki kepuasan pernikahan rendah. Penelitian yang dilakukan Wulan dan Chotimah (2018), mengatakan dari hasil penelitian yang didapat terdapat kepuasan pernikahan remaja awal yang tinggi maupun rendah. Ketika remaja ini mencapai kepuasan pernikahannya, maka ia akan merasa bahagia akan pernikahannya dan hal tersebut berdampak pada peran yang ia jalani dalam pernikahan. Serta akan merasa bersyukur atas pernikahannya dan dapat dipastikan ketika menemui konflik dalam rumah tangga, konflik tersebut akan dapat diatasi sehingga kecil kemungkinan perpisahan atas pernikahan yang telah dijalani tersebut.

\section{SIMPULAN DAN IMPLIKASI}

Berdasarkan hasil penelitian yang telah dilakukan dapat disimpulkan bahwa terdapat pengaruh antara komunikasi efektif faktor-faktor lain yang mendukung kepuasan pernikahan antara lain masa kanak-kanak, pendidikan, tingkat kesetaraan, ekspresi kasih sayang terhadap pasangan. Jika dilihat uji beda komunikasi efektif, 
tidak terdapat perbedaan komunikasi efektif suami dan istri.. Akan tetapi jika dilihat dari kepuasan pernikahannya terdapat perbedaan kepuasan pernikahan suami dan istri.. Dilihat dari usia 15 dan 18 memiliki komunikasi efektif yang tinggi sedangkan usia 14, 16, 17, dan 19 memiliki komunikasi efektif yang rendah. Untuk kepuasan pernikahan usia 15, 17, dan 19 memiliki kepuasan pernikahan yang tinggi sedangkan usia 14, 16, dan 18 memiliki kepuasan pernikahan rendah.

Implikasi dari penelitian ini adalah untuk pasangan yang melakukan pernikahan dini, pernikahan yang baik bukan berarti pernikahan yang bebas dari permasalahan, melainkan bagaimana cara pasangan tersebut mengatasi masalah dalam pernikahannya. Penyelesaian masalah tersebut dapat berpengaruh terhadap tingginya kepuasan pernikahannya ketika mengkomunikasikan apa yang dirasakan dengan sikap yang jujur apaadanya. Komunikasi yang baik adalah komunikasi efektif karena komunikasi ini dilakukan secara terus menurus sehingga menjadi komunikasi yang lebih baik lagi. Pasangan yang melakukan komunikasi efektif disarankan saat melakukan komunikasi sebaiknya tidak memotong pembicaraan dari lawan bicara, menerima masukan yang diberikan serta menjalaninya, menyelesaiakn konflik secara bersama. Jika masalah tersebut tidak diselesaikan akan berpengaruh terhadap kepuasan pernikahan yang berdampak terhadap kehidupan seksual yang menurun, kemudian hubungan dengan pasangan tidak harmonis, dan akan berakibat tingginya percerai.

Bagi peneliti selanjutnya diharapkan mengembangkan kembali instrumen dari komunikasi efektif dan kepuasan pernikahan. Selain itu, apabila ingin meneliti mengenai pasangan yang menikah dini untuk mempertimbangkan lokasi dan waktu penelitian. Hal tersebut dikarenakan setiap desa belum tentu memiliki banyak pasangan yang menikah dini.

\section{REFERENSI}

Afianti, T. (2018). Psikologi perkawinan dan keluarga. Yogyakarta: PT Kanisius.

Alder, E.S. (2010). Age, education level and length of courtship in relation to marital satisfaction. (Tesis, Pacific University, United States).

Ali, M., Asrori, M. (2012). Psikologi remaja, perkembangan perserta didik. Jakarta: PT Bumi Aksara.

Amalia, V. \& Ratnasari, Y. (2017). Kepuasan pernikahan berhubungan dengan kecenderungan berselingkuh. Jurnal Ilmu Perilaku Vol.1 No.1 (45-57).

Atta, et al. (2013). Role of trust in marital satisfaction among single and dual career couples. Journal of Internet Psychology, 2, (4), 53-62.

Atiqoh, S. (2014). Pengaruh komunikasi efektif dan kecerdasan emosional terhadap kebahagiaan pasangan suami istri. Skripsi. Fakultas Psikologi Universitas Islam Negeri Syarif Hidayatullah.

Ayub, N. (2010). Development of marital satisfaction scale. Pakistan Journal of Clinical Psychology. Institute of Clinical Psychology, Universit of Karachi. Vol 9, No. 1. 1934.

Azwar, S. (2003). Penyusunan skala psikologi. Yogyakarta: Pustaka Pelajar.

Bagwell, E. K. (2006). Factors influencing marital satisfaction with a specific focus on depression. Senior Honor Theses, 38. 
Batool, S. S. \& Khalid, R. (2012). Emotional intelligence: a predictor of marital quality in Pakistan couples. Pakistan Journal of Psychology Research, 27(1), 65-88.

Bradbury, T. N., Beach, R. H. S., \& Fincam, F. D. (2000). Research on the nature and determinants of marital satisfaction: a decade in review. Journal of Marriage and Family.

Canary, D. J., Stafford, L., \& Semic, B. A. (2002). A panel study of the associations between maintenance strategies and relational characteristics. Journal of Marriage and Family, 64(2), 395-406.

Dayan, N. A., Magno, E. T. T., \& Taroja, M. C. H. (2001). Marriages made on earth Manila, Philippine: De La Salle University Press Inc.

Desmita. (2006). Psikologi perkembangan. Bandung: PT Remaja Rosdakarya.

Duvall \& Miller. (1985). Marriage and Family Development. Edisi Keenam. New York: Haper \& Row, Publishers.

Doss, B. D., Rhoades, G. K., Stenly, S. M., \& Markman, H. J. (2009). Marital therapy, retreats, and books: the who, what, when, and why of relationship help-seeking. Journal of Marintal and Family Therapy. 35(1). 18-29.

Estere, M. O. (2014). Obstacles and suggested solutions to effective communication in marriage as expressed by married adults in Kogi State, Nigeria. Journal Social and Behavioral Science, 114. 584-592.

Fowers B. J. \& Olson, D. H. (1989). ENRICH marital inventory: a discrimant validity and cross-validity assesment. Journal of Marital and Family Therapy Vol 15. No. 1, 65 - 79.

Humaira, H. (2018). Komunikasi interpersonal dan kepuasan pernikahan pada pasangan yang baru menikah. Skripsi. Fakultas Psikologi Universitas Muhammadiyah Malang.

Hermawan, H. (2010). Pengaruh pernikahan dini terhadap perceraian dini (studi kasus di pengadilan agma klaten. Skripsi. Fakultas Syaria'ah dan Hukum, Universitas Islam Negeri Sunan Kalijaga Yogyakarta.

Kristanto, D. P. H. \& Setyaningrum, M. E. (2018) Kepuasan Pernikahan pada Suami dengan Istri sebagai Pencari Nafkah Utama. Jurnal Psikohumanika Vol 10 No 02 (15-30).

Mohammad, M. D. (2005). Jeratan nikah dinii, wabah pergaulan. Jogjakarta: Media Abadi.

Nana, D. \& Helmy, Y. (2019). Hamil duluan nikah belakangan, angka pernikahan dini di kabupaten malang tak terkendali. (diakses pada tanggal 14 April 2019 pukul 17:44 dari https://www.malangtimes.com/baca/36208/20190218/175300/hamil-duluan-nikahbelakangan-angka-pernikahan-dini-di-kabupaten-malang-tak-terkendali)

Nurmaya, Y. (2016). Hubungan antara Komunikasi Efektif dan Kepuasan Perkawinan pada Istri Suku Jawa. Skripsi. Fakultas Psikologi Universitas Sanata Dharma.

Olson, D. H., DeFrain, J., \& Skogrand, L. (2011). Marriages and families ( ${ }^{\text {th }}$ ed). New York: McGraw-Hill

Osakinle, E.O., \& Okafor, V.C. (2013). Lack of effective communication among couples in ekiti state, Nigeria. Asian Journal of Education and e-Learning, 01(05), 23212454.

Punyanunt-Carter, N.M. (2004). Using equity to examine relationship maintenance and satisfaction in father-daughter relationship. Human Communicatin a Publication of the Pacific and Asian Communication Association, 11(1), 157-172.

Rakhmat, J. (2000). Psikologi Komunikasi Efektif. Bandung: PT. Remaja Rosdakarya. 
Robinson, L.C \& Blanton, P. W. (1993). Material strengths in enduring marriages. Journal of Family Relations, Volume 42, (38-4).

Rosen-Grandon, J., Myers, J., \& Hattie, J. (2004).The relationship between maritalcharacteristics, marital interaction processes, and marital satisfaction. Journal of Counseling and Development, 82, 58-68.

Santrock, J.W. (2007). Remaja. Jakarta: Penerbit Erlangga.

Santrock, J.W. (2012). Life-span development. (terj. Benedictine Wisdyasinta). Jakarta: Erlangga.

Snyder, K. D. (1997). Multidimensional Assessment of Marital Satisfaction. Journal of Marriage and Family, 41(4), 813-823.

Srisusanti, S \& Zulkaida, A. (2013). Studi Deskriptif Mengenai Faktor-Faktor yang Mempengaruhi Kepuasan Pernikahan. Jurnal Psikologi Vol.07 No. 06 (08-12).

Sugiyono. (2017). Metode penelitian pendidikan. Bandung: CV. Alfabet.

Tavakolizadeh, J., Nejatian, M., \& Soori, A. (2015). The Effectiveness of communication skills training on marital conflicts and its different aspects in women. Procedia - Social and Behavioral Sciences.

Tiara, M \& Qudsyi, H. (2018). Citra Tubuh dan Kepuasan Pernikahan Istri pada Usia Tengah. Jurnal Psikologi Vol 01 No 02 (76-85).

Vanhorn, S.C. (2010). The communication, speech \& theatre association of northdakota. Journal of the Communication, Speech \& Theatre Association of North Dakota, 23, 1-87.

Walgito, B. (2002). Bimbingan konseling dan perkawinan. Yogyakarta: Andi.

Weinstein, L., Powers, J. \& Laverghetta, A. (2010). College students' chronological age predicts marital happiness regardless of length of marriage. College student journal, 44 (22). 